\title{
Potential use as a bio-preservative from lupin protein hydrolysate generated by alcalase in food system
}

\author{
Ali Osman ${ }^{1 *}$, Ghada M. El-Araby ${ }^{2}$, Hefnawy Taha ${ }^{1}$ \\ ${ }^{1}$ Biochemistry Department, Faculty of Agriculture, Zagazig University, Zagazig 44511, Egypt. \\ ${ }^{2}$ Food Science Department, Faculty of Agriculture, Zagazig University, Zagazig 44511, Egypt.
}

\begin{tabular}{|c|c|}
\hline ARTICLE INFO & ABSTRACT \\
\hline $\begin{array}{l}\text { Article history: } \\
\text { Received on: } 20 / 01 / 2016 \\
\text { Revised on: } 25 / 02 / 2016 \\
\text { Accepted on: } 02 / 04 / 2016 \\
\text { Available online: } 21 / 04 / 2016\end{array}$ & $\begin{array}{l}\text { In this study, we evaluated the antibacterial activity of hydrolysates from lupin protein in vitro against gram } \\
\text { positive (Staphylococcus aureus and Bacillus subtilis) and gram negative (Pseudomonas aeruginosa and } \\
\text { Escherichia coli) bacteria and in food system (in minced beef under refrigerated condition).Hydrolysis of lupin } \\
\text { protein with Alcalase was monitored for } 4 \mathrm{~h} \text {. Hydrolysates obtained after } 1,2,3 \text { and } 4 \mathrm{~h} \text { had degree of } \\
\text { hydrolysis values of } 9 \%, 16 \%, 23 \% \text { and } 25 \% \text {, respectively. The minimal inhibitory concentration (MIC) of LPH } \\
\text { was determined against all bacterial strains. MIC value of LPH against all bacterial strains was } 100 \mu \mathrm{g} \mathrm{ml} \mathrm{m}^{-1} \text {. The }\end{array}$ \\
\hline $\begin{array}{l}\text { Key words: } \\
\text { Lupin protein; Antibacterial; } \\
\text { Minced beef; Hydrolysis; } \\
\text { Alcalase; Antibacterial } \\
\text { activity. }\end{array}$ & $\begin{array}{l}\text { results showed that gram positive bacteria were more sensitive than gram negative bacteria. Adding LPH at } \\
\text { different concentrations }(100,150 \text { and } 200 \mu \mathrm{g} / \mathrm{g}) \text { to minced beef showed antibacterial activity during storage at } \\
4^{\circ} \mathrm{C} \text { compared to nisin }(200 \mu \mathrm{g} / \mathrm{g}) \text { as a positive control. The results of this study showed that enzymatic } \\
\text { hydrolysis by Alcalase at } \mathrm{pH} 7.8 \text { and } 55^{\circ} \mathrm{C} \text { for } 240 \text { min is an easy tool to increase the antibacterial activity of } \\
\text { lupin protein against both gram negative and gram positive bacteria and can be used as a bio-preservative in food } \\
\text { system. Extending the technological validity of minced beef will help avoid big losses of minced beef and } \\
\text { enhance its chances to be incorporated into many meat products while avoiding hygienic, chemical and } \\
\text { technological deterioration. }\end{array}$ \\
\hline
\end{tabular}

\section{INTRODUCTION}

The problems of spoilage and food poisoning, mainly by oxidation processes or by microorganism activity, during production and storage are still concerns for both the food industry and consumers, despite the use of synthetic chemical additives and various preservation methods [1-3]. Ground beef is a perishable product with noted food safety concerns because it provides a favorable medium for the growth of both spoilage and food-borne microorganisms. It is frequently contaminated by microorganisms due to excessive handling, (i.e. slaughtering, processing and transporting). In fact, food poisoning is still a threat for both consumers and the food industry despite the use of preserving processes. Meanwhile, consumers are concerned about the safety of foods containing preservatives. Therefore, there has been a growing interest in new and effective techniques

\footnotetext{
* Corresponding Author

E-mail: Ali_khalil2006@yahoo.com; Tel: +201289183858
}

to reduce cases of food-borne illnesses. Preservatives in foods are regarded as 'chemical' additives and 'unnatural' by many consumers and are rejected for this reason. Natural alternatives, in contrast, have a much better image. For several years, basic proteins, spices, herbs and herbal extracts with antimicrobial activities have been discussed in this context [4-15]. The biodiversity of plants provides an important source of chemical compounds, which have many therapeutic applications such as antiviral, antibacterial, antifungal and anticancer activities [16]. Legumes play an important role in the traditional diets of many regions throughout the world [17-18]. In particular, lupin seeds are characterized by a virtually non-existent starch and high protein content (total protein content of approximately 34\%) in comparison to other legumes such as beans and peas [19].

A number of strategies have been suggested to improve the antimicrobial activities of proteins, including chemical modification such as esterification [20] and enzymatic hydrolysis using digestive proteases , microbial and plant Proteolytic enzymes $[21,22]$. Alcalase is a bacterial extract from Bacillus licheniformis [23] containing several proteinases with different specificities. 
Alcalase has been used extensively to prepare soluble hydrolysates of soy protein [24] and fish protein [25] as well as to produce bioactive peptides [26, 27]. The antibacterial activity of lupin seeds protein hydrolyzed with alaclase has been not studied. Therefore, the aim of this work was to hydrolyze lupin protein by alcalase and evaluate the antibacterial activity of these hydrolysates (LPH) against selected pathogenic and spoilage bacteria to test their potential use as bio-preservatives in food.

\section{MATERIAL AND METHODS}

\subsection{Plant Material}

Lupinseeds (Lupinus angustifolius L.) seeds were purchased from local market, Zagazig, Sharkia governorate, Egypt.

\subsection{Meat Samples}

The fresh raw beef purchased from local market in Zagazig city, Sharkia government, Egypt was finely minced in sanitized meat mincers. The samples of the minced meat were transferred to sterilized polyethylene sachets.

\subsection{Microorganisms}

Gram positive bacteria (Staphylococcus aureus and Bacillus subtilis) and Gram negative bacteria (Pseudomonas aeruginosa and Escherichia coli), were kindly obtained from Laboratory of Microbiology, Department of microbiology, Faculty of Science, Zagazig University, Egypt.

\subsection{Animals}

Healthy male white albino rats (Rattus norvegicus), Wistar strain $(160 \pm 10 \mathrm{~g}$, body wt) were obtained from Organization of Biological Products \& Vaccine (Helwanfarm, Cairo, Egypt) and housed in plastic cages in groups of 5 animals/cage. The experimental animals were allowed to acclimatize under the laboratory conditions (temperature of $25 \pm 5$ ${ }^{\circ} \mathrm{C}$; relative humidity $50-70 \%$ and normal light/ dark cycle) for 2 weeks at least prior the experiment. They were provided with balanced pelleted diet (23\% protein) and tap water ad libitum throughout the adaptation and experimental period.

\subsection{Lupin Protein Isolate (LPI) Isolation}

Lupin seeds were manually cleaned and ground using a Moulinex mixer (Type 716, France) at a maximum speed and the meal was ground to pass through a $1 \mathrm{~mm}^{2}$ sieve. The powder was then defatted using chloroform: methanol (3:1v/v) for $8 \mathrm{~h}$. Solvent was evaporated by rotary-evaporator and dried-defatted meal was used to separate LPI from Lupin seeds at $\mathrm{pH} 4.5$ according to Johnson and Brekke [28].

\subsection{Preparation of Lupin Protein Hydrolysate (LPH)}

Lyophilized LPI was dissolved in distilled water $(100 \mathrm{~g} / \mathrm{L})$ and hydrolyzed batch-wise by treatment with Alcalase $(\mathrm{E} / \mathrm{S}$ ratio of $1: 200(\mathrm{w} / \mathrm{w}))$ at $55{ }^{\circ} \mathrm{C}$ and $\mathrm{pH}$ 7.8. The hydrolysis was allowed to proceed for $240 \mathrm{~min}$, the $\mathrm{pH}$ was kept at 7.8 during hydrolysis by addition of $1 \mathrm{M} \mathrm{NaOH}$ and the degree of hydrolysis (DH) was determined every 60 min during hydrolysis according to Adler-Nissen [29]. At the end of hydrolysis, the enzyme was inactivated by heating at $80{ }^{\circ} \mathrm{C}$ for $20 \mathrm{~min}$. Hydrolysate was clarified by centrifugation at $4000 \mathrm{~g}$ for $30 \mathrm{~min}$ at $16{ }^{\circ} \mathrm{C}$ to remove insoluble substrate fragments, and the supernatant was lyophilized and freeze at $-20^{\circ} \mathrm{C}$ until further use.

\subsection{Acute Toxicity}

According to OECD guideline for testing of chemicals [30]. Twenty male Wistar Albino rats (160 $\pm 10 \mathrm{~g}$, body wt.) were divided into four groups, 5 rats each. All treatments were delivered by gavage as dissolved in $2 \mathrm{mLdistilled} \mathrm{water.} \mathrm{The} \mathrm{first} \mathrm{group}$ received $2 \mathrm{~mL}$ distilled water free from any external treatment. The groups 2, 3 and 4 received one single dose of LPH of 2000, 2500 and $5000 \mathrm{mg} / \mathrm{kg}$ body wt.), respectively. All rats were kept under observation for $24 \mathrm{~h}$ for recording any symptoms of toxicity or mortality and maintained for further 14 days to observe behavioral and body weight changes.

\subsection{Antibacterial Activity of LPH Against Gram Positive and Gram Negative Bacteria}

LPH was tested for antimicrobial activity against gram positive bacteria ( $S$. aureus and B. subtilis) and gram negative bacteria (P. aeruginosa and E. coli) by conventional well-diffusion assay [31]. The pure cultures of bacterial strains were sub-cultured on Mueller Hinton broth (MHB) and incubated on a rotary shaker at $200 \mathrm{rpm}$ at $37^{\circ} \mathrm{C}$ (S. aureus, P. aeruginosa and E. coli) or $28^{\circ} \mathrm{C}$ (B. subtilis) for $24 \mathrm{~h}$. An aliquot $(0.1 \mathrm{ml})$ of the last culture was transferred into $10 \mathrm{ml}$ MHB and incubated at $37^{\circ} \mathrm{C}(S$. aureus, $P$. aeruginosa and E. coli) or $28^{\circ} \mathrm{C}$ (B. subtilis) for $24 \mathrm{~h}$ to reach a count of $1.05 \times 10^{9} \mathrm{CFU} / \mathrm{ml}$. Each strain was spread uniformly onto individual plates using sterile cotton swabs. Wells of6-mm diameters were made on Mueller Hinton Agar (MHA) plates using gel puncture. Aliquots $(40 \mu \mathrm{l})$ of LPH concentrations $(50,100$, 150,200 and $250 \mu \mathrm{g} / \mathrm{ml}$ ) were transferred onto each well of all plates. Negative control (sterilized distilled water) was carried out. After incubation at at $37{ }^{\circ} \mathrm{C}($ S. aureus, P. aeruginosa and E. coli) or $28{ }^{\circ} \mathrm{C}$ (B. subtilis) for $24 \mathrm{~h}$, the different levels of zones of inhibition were measured using a transparent ruler and the diameter was recorded in $\mathrm{mm}$ to conclude the minimum inhibitory concentration (MIC).

\subsection{Storage of Minced beef with LPH under Refrigeration Conditions}

Minced beef samples $(100 \mathrm{~g})$ were placed in stomacher bags and homogenized in a stomacher for $2 \mathrm{~min}$ at room temperature. Following homogenization LPH was added to the samples. Treatment of the samples included no addition (negative control), addition of LPH at $100 \mu \mathrm{gg}^{-1}, 150 \mu \mathrm{gg}^{-1}$ and $200 \mu \mathrm{gg}^{1}$. Tests using nisin $\left(200 \mathrm{\mu gg}^{-1}\right)$ as positive control was carried out in parallel. All stomacher bags with samples from all treatments were wrapped and stored under aerobic conditions at $4{ }^{\circ} \mathrm{C}$ for 15 days. 
Antioxidant analysis and microbiological analysis of samples were carried out at different intervals of preservation (0-15 days) at $4{ }^{\circ} \mathrm{C}$.

\subsubsection{Lipid peroxidation assay}

Lipid peroxidation in the minced beef supplemented with

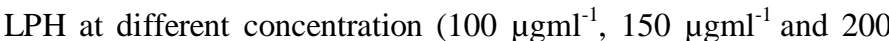
$\mu \mathrm{gml}^{-1}$ ) was measured using the method of Niehius and Samuels on [32] after different intervals of preservation (0-15 days) at $4{ }^{\circ} \mathrm{C}$. Five gram of each meat sample was homogenized. A volume of $10 \% \mathrm{w} / \mathrm{v}$ homogenate was prepared in $0.05 \mathrm{M}$ phosphate buffer $(\mathrm{pH} 7)$ and centrifuged at $12,000 \times \mathrm{g}$ for $60 \mathrm{~min}$ at $4{ }^{\circ} \mathrm{C}$. The supernatant obtained was used for lipid peroxidation assessment. $100 \mu \mathrm{l}$ from supernatant was treated with $2000 \mu \mathrm{l}$ of (1:1:1 ratio) TBA-TCA-HCl reagent (thiobarbituric acid $0.37 \%$, $15 \%$ trichloroacetic acid and $0.25 \mathrm{~N} \mathrm{HCl}$ ). All the tubes were placed in a boiling water bath for $30 \mathrm{~min}$ and allowed to cool. The amount formed in each of the samples was assessed by measuring the optical density of the supernatant at $535 \mathrm{~nm}$ using JENWAY 6405 UV/visible spectrophotometer (UK) against a reagent blank. Percentage inhibition was calculated using the equation: Lipid oxidation inhibition (\%)

$=[1-($ absorbance of sample/absorbance of control $)] \times 100$

\subsubsection{Microbial analysis}

Microbial analysis of minced beef supplemented with LPH at different concentration $\left(100 \mu \mathrm{gml}^{-1}, 150 \mu \mathrm{gml}^{-1}\right.$ and 200 $\left.\mu \mathrm{gml}^{-1}\right)$ compared to nisin $(200 \mu \mathrm{g} / \mathrm{g})$ as a positive control was assessed after different intervals of preservation (0-15 days) at $4{ }^{\circ} \mathrm{C}$ followed the procedures outlined in APHA [33]. The samples $(10 \mathrm{~g})$ were transferred aseptically to a stomacher bag containing $90 \mathrm{ml}$ of peptone saline diluent $(1.0 \mathrm{~g}$ peptone and $8.5 \mathrm{~g}$ sodium chloride in 1 liter of distilled water) at room temperature and homogenized for $60 \mathrm{~s}$. A serial 10-fold dilution series was prepared. Determinations were carried out for different bacterial counts using different specific selective media [34] as follows total viable count (TVC) was enumerated on Plate Count Agar (PCA, Merck, Darmstadt, Germany) at $25{ }^{\circ} \mathrm{C}$ after $72 \mathrm{~h}$, psychrotrophs were counted on PCA (Merck, Darmstadt, Germany) at $7{ }^{\circ} \mathrm{C}$ after 10 days and coliformbacteria was determined by MacConkey agar (Mast Group, Merseyside, UK) with a double layer of the same medium incubated at $37{ }^{\circ} \mathrm{C}$ for $24 \mathrm{~h}$. Microbiological data were transformed into logarithms of the number of colony forming units (CFU/g).

\subsection{Technological and Sensorial Qualities \\ 2.10.1 Preparation of beef burger}

Minced beef samples were used for beef burger manufacture with these ingredients: minced beef; $1000 \mathrm{~g}$, fat; $21 \mathrm{~g}$, fresh onion; $3 \mathrm{~g}$, sodium chloride; $20 \mathrm{~g}$, black pepper; $50 \mathrm{~g}$, coriander; $30 \mathrm{~g}$, clove; $5 \mathrm{~g}$ and cinnamon; $5 \mathrm{~g}$ ) which were minced twice. Treatment of the samples included no addition (negative

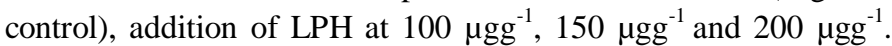
Addition of nisin $\left(200 \mu \mathrm{gg}^{-1}\right)$ as positive control. Meat mixture was shaped manually using patty maker to obtain round disks $9.5 \mathrm{~cm}$ diameter and $0.5 \mathrm{~cm}$ thickness. Burgers were packed in polyethylene bags in foam dish.

All burger beef treatments were grilled on hot plate with little sunflower oil at $110{ }^{\circ} \mathrm{C}$ for $4 \mathrm{~min}$. Then the cooking loss percentage was calculated from following equation according to A.O.A.C. [35].

Cooking loss $(\%)=$

$$
\frac{\text { Fresh burger weight }- \text { Cooked burger weight }}{\text { (Fresh burger weight)X100 }}
$$

Shrinkage percentage was calculated from this equation according to A.O.A.C. [35].

$$
\text { Shrinkage }(\%)=(a-b)+(c-d) \times 100
$$

The thickness of uncooked burger (a), the thickness of grilled burger (b), the diameter of uncooked burger (c) and the diameter of grilled burger (d).

Sensory evaluation was conducted according to the method described by Mansour and Khalid [36]. Cooked burger samples were served warm to 10 panelists (staff of food science Department, Faculty of Agriculture, Zagazig University, Egypt) without care of age or sex. The panelists were subjected to sensory evaluation using an 8 point hedonic scale for appearance color, juiciness, tenderness flavor and overall acceptability. A numerical basis as assort of evaluation from 1-8 was used where (1=dislike extremely, $2=$ dislike very much, $3=$ dislike moderately, $4=$ dislike slightly, 5= like slightly, $6=$ like moderately, $7=$ like very much, $8=$ like extremely).

\subsection{Statistical Analysis}

All biological trials and measurements were conducted in triplicate and expressed as the mean plus the standard error. ANOVA variance analysis was used for the statistical analysis of data using the general linear models (GLM) procedure of the SAS software (version 9.1, SAS Institute, Inc., 2003). Least significant differences were used to compare means at $p<0.05$.

\section{RESULTS AND DISCUSSION}

\subsection{Production of LPH}

Alcalase was used to produce bioactive peptides from proteins $[21,26]$. In the present study, hydrolysis of LPI with Alcalase was monitored for $4 \mathrm{~h}$. Hydrolysates obtained after 1, 2, 3 and $4 \mathrm{~h}$ had $\mathrm{DH}$ values of $9 \%, 16 \%, 23 \%$ and $25 \%$, respectively. The high DH values are consistent with the broad specificity of Alcalase. Similar DH values were reported by Osman et al. [21] from Alcalase hydrolysis (4h) of goat milk proteins. Also from hydrolysis of barbel muscle protein by Alcalase nearly similar DH values were obtained after 1 and $2 \mathrm{~h}$ but the final $\mathrm{DH}$ was lower [27].

\subsection{Acute Toxicity}

No death or hazardous signs were recorded in rats during 14 days of observation after acute treatment by oral route with 
LPH in doses of 2,000, 2,500 and 5,000 mg/kg body weight. The absence of mortality after single administration of very high doses (up to $5,000 \mathrm{mg} / \mathrm{kg}$ body weight/day) of LPH during acute toxicology test indicates the safety of this protein and suggesting a lethal dose $50 \%\left(\mathrm{LD}_{50}\right)$ above $5,000 \mathrm{mg} / \mathrm{kg}$ body weight. No signs of overt toxicity were observed in any group $24 \mathrm{~h}$ after dosing and no abnormal breathing, impaired movements, etc. were noticed in any rat group. Observation of treated animals over the next 14 days showed no adverse effects of these treatments.

\subsection{Antibacterial Activity}

Antibacterial activity of LPH against gram negative and gram positive bacteria was evaluated by agar well diffusion method. LPH exhibited antibacterial activity against all tested bacteria (Table 1). The minimal inhibitory concentration (MIC) of LPH was determined against all bacterial strains. MIC value of LPH against all bacterial strains was $100 \mu \mathrm{g} \mathrm{ml}^{-1}$. The results showed that $\mathrm{G}^{+}$bacteria were more sensitive than $\mathrm{G}^{-}$bacteria due to a unique outer membrane in $\mathrm{G}^{+}$bacteria that determines permeability and susceptibility of the cells to the antibacterial agents [37].

\subsection{Storage of Minced Beef with LPH under Refrigeration Conditions}

\subsubsection{Microbial analysis}

The results presented in table 2 show the changes in the levels of total viable count (TVC) in minced beef preserved at $4{ }^{\circ} \mathrm{C}$ for 15 days as supplemented with LPH at different concentrations $(100,150$ and $200 \mu \mathrm{g} / \mathrm{g})$ compared to nisin $(200 \mu \mathrm{g} / \mathrm{g})$ as a positive control. It can be observed that TVC of all treated minced beef samples were significantly different from the negative control group. TVC increased gradually with time and reached the $7 \mathrm{log}$ CFU/g after 7, 10, 10, 10 and 15 days for control, nisin $(200 \mu \mathrm{g} / \mathrm{g})$,
LPH $(100 \mu \mathrm{g} / \mathrm{g}), \quad$ LPH $(150 \mu \mathrm{g} / \mathrm{g})$ and LPH $(200 \mu \mathrm{g} / \mathrm{g})$ respectively.

\subsubsection{Lipid peroxidation}

The inhibition against lipid oxidation in minced beef supplemented with LPH at different concentration (100, 150 and $200 \mu \mathrm{g} / \mathrm{g}$ ) and storage at $4{ }^{\circ} \mathrm{C}$ for 15 days compared to control was shown in Figure 1.

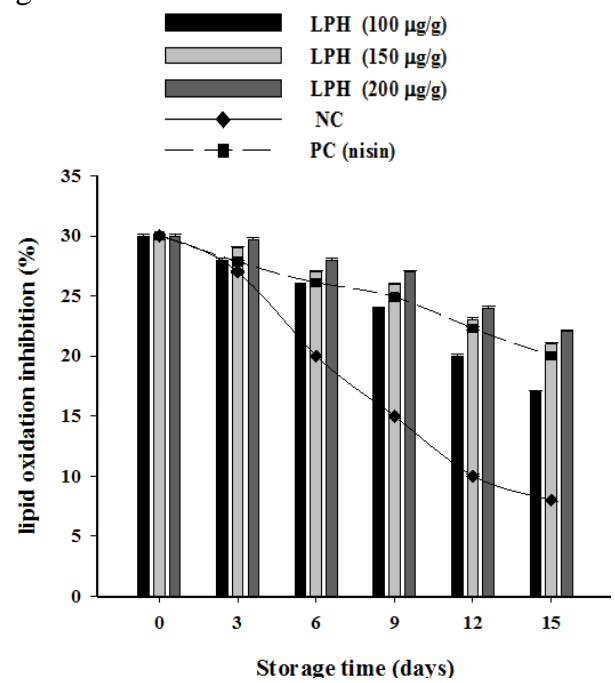

Fig. 1: Lipid oxidation inhibition (\%) in minced beef (negative control; NC)as supplemented with LPH at different concentrations $(100,150$ and $200 \mu \mathrm{g} / \mathrm{g})$ and stored at $4{ }^{\circ} \mathrm{C}$ for different periods (0-15 day) compared to nisin $(200 \mu \mathrm{g} / \mathrm{g})$ as a positive control (PC).

Untreated minced beef showed much decreasing in inhibition against lipid oxidation (8.67 \pm 0.053$)$ than minced beef supplemented with $\mathrm{LPH}(100,150$ and $200 \mu \mathrm{g} / \mathrm{g})$ and nisin $(200$ $\mu \mathrm{g} / \mathrm{g})(18 \pm 0.021,22.34 \pm 0.043,25 \pm 0.06$ and $23.13 \pm 0.023)$ respectively, after 15 days storage at $4{ }^{\circ} \mathrm{C}$ compared to zero time (30 \pm 0.013$)$.

Table 1: Antibacterial activity of LPH at different concentrations $\left(50-250 \mu \mathrm{g} \mathrm{ml}^{-1}\right)$ against $\mathrm{Gram}^{+}($Staph. aureus and B. subtilis) and Gram( $(P$. aeruginosa and $E$. coli) bacteria using agar well diffusion assays.

\begin{tabular}{|c|c|c|c|c|c|}
\hline \multirow{2}{*}{ Microorganisms } & \multicolumn{5}{|c|}{ Inhibition zone diameter (mm) } \\
\hline & $50 \mu \mathrm{g} \mathrm{ml}^{-1}$ & $100 \mu \mathrm{g} \mathrm{ml}^{-1}$ & $150 \mu \mathrm{g} \mathrm{ml}^{-1}$ & $200 \mu \mathrm{g} \mathrm{ml}^{-1}$ & $250 \mu \mathrm{g} \mathrm{ml}^{-1}$ \\
\hline \multicolumn{6}{|c|}{ Gram positive bacteria } \\
\hline Staph. aureus & - & $24^{\mathrm{a}} \pm 0.3$ & $27^{\mathrm{a}} \pm 0.3$ & $33^{\mathrm{a}} \pm 0.5$ & $39^{a} \pm 0.7$ \\
\hline B. subtilis & - & $15^{\mathrm{b}}$ & $21^{\mathrm{b}} \pm 0.21$ & $27^{\mathrm{a}} \pm 0.4$ & $33^{\mathrm{b}} \pm 0.5$ \\
\hline \multicolumn{6}{|c|}{ Gram negative bacteria } \\
\hline P. aeruginosa & - & $11^{\mathrm{b}}$ & $13^{\mathrm{c}} \pm 0.2$ & $17^{\mathrm{b}} \pm 0.3$ & $25^{\mathrm{c}} \pm 0.5$ \\
\hline E. coli & - & $9^{\mathrm{bc}} \pm 0.11$ & $12^{\mathrm{c}} \pm 0.11$ & $16^{\mathrm{b}} \pm 0.4$ & $21^{\mathrm{c}} \pm 0.22$ \\
\hline
\end{tabular}

Table 2: Total viable count in minced beef (negative control; NC)as supplemented with $\mathrm{LPH}$ at different concentrations $(100,150 \mathrm{and} 200 \mu \mathrm{g} / \mathrm{g})$ and stored at $4{ }^{\circ} \mathrm{C}$ for different periods ( $0-15$ day) compared to nisin $(200 \mu \mathrm{g} / \mathrm{g})$ as a positive control (PC).

\begin{tabular}{|c|c|c|c|c|c|}
\hline \multirow{3}{*}{ Storage time (days) } & \multirow{2}{*}{$\mathrm{NC}$} & \multirow{2}{*}{$\begin{array}{c}\text { PC } \\
(\text { Nisin; } 200 \mu \mathrm{g} / \mathrm{g})\end{array}$} & \multicolumn{3}{|c|}{ LPH } \\
\hline & & & $100 \mu \mathrm{g} / \mathrm{g}$ & $150 \mu \mathrm{g} / \mathrm{g}$ & $200 \mu \mathrm{g} / \mathrm{g}$ \\
\hline & \multicolumn{5}{|c|}{ Log cfu/g } \\
\hline $\mathbf{0}$ & $2^{c} \pm 0.09$ & $2^{\mathrm{c}} \pm 0.09$ & $2^{\mathrm{c}} \pm 0.09$ & $2^{\mathrm{c}} \pm 0.09$ & $2^{c} \pm 0.09$ \\
\hline 3 & $3.7^{\mathrm{c}} \pm 0.11$ & $2^{\mathrm{c}} \pm 0.07$ & $2.4^{\mathrm{c}} \pm 0.06$ & $2.2^{\mathrm{c}} \pm 0.08$ & $2^{\mathrm{c}} \pm 0.15$ \\
\hline 6 & $5.4^{\mathrm{b}} \pm 0.15$ & $3.6^{c} \pm 0.09$ & $3.7^{\mathrm{b}} \pm 0.05$ & $3.4^{\mathrm{c}} \pm 0.09$ & $3^{c} \pm 0.12$ \\
\hline 7 & $7.3^{\mathrm{b}} \pm 0.18$ & $4.9^{c} \pm 0.11$ & $5.1^{\mathrm{b}} \pm 0,11$ & $4.5^{\mathrm{b}} \pm 0.11$ & $4.3^{\mathrm{b}} \pm 0.18$ \\
\hline 10 & $8^{\mathrm{a}} \pm 0.21$ & $6.9^{\mathrm{b}} \pm 0.08$ & $7.2^{\mathrm{a}} \pm 0.13$ & $6.8^{\mathrm{a}} \pm 0.14$ & $5.3^{\mathrm{b}} \pm 0.2$ \\
\hline 15 & $9.3^{\mathrm{a}} \pm 0.19$ & $8.3^{\mathrm{a}} \pm 0.16$ & $8.6^{\mathrm{a}} \pm 0.18$ & $7.5^{\mathrm{a}} \pm 0.21$ & $6.7^{\mathrm{a}} \pm 0.22$ \\
\hline
\end{tabular}




\subsection{Technological and Sensorial Qualities}

Lupins (Lupinus angustifolius) have been suggested as a potential substitute for soybeans in Asian Food. Much research has been done using lupin as a substitute for soybean in soy milk and tofu. Furthermore lupin is a high protein seed and their protein has many properties [38]. Therefore, the potential of using lupins protein as a nutraceutical food supplement and additive in Asian Foods is tremendous. Our own investigation in table 3 has shown that lupin protein can improve the color, water absorption, protein level and eating qualities of fortified burger, that through the reduction of cooking loss $\%$ and Shrinkage \% gradually by increasing of concentration from $(33.4 \%$, and $23.1 \%)$ in control sample to $26.8 \%$, and $10.5 \%$ in positive sample (nicin $200 \mu \mathrm{g} / \mathrm{g}$ ) respectively, which was nearest value compare to the highest concentration of lupin protein additives that probably due to the high total digestible nutrients (TDN) in the lupin [39]. The obtained results are in harmony with Mahmoud et al. [40] who observed decreased in cooking loss as the amount of protein was increased in meat products.

Table 3: Cooking loss and shrinkage percentages in beef burger (negative control) as supplemented with LPH at different concentrations (100, 150 and $200 \mu \mathrm{g} / \mathrm{g})$ compared to nisin $(200 \mu \mathrm{g} / \mathrm{g})$ as a positive control.

\begin{tabular}{lcc}
\hline Samples treatments & Cooking loss \% & Shrinkage \% \\
\hline Negative control & $33.4^{\mathrm{a}}$ & $23.1^{\mathrm{a}}$ \\
Positive control (Nisin; $200 \mu \mathrm{g} / \mathrm{g})$ & $26.8^{\mathrm{a}}$ & $10.5^{\mathrm{c}}$ \\
LPH $(100 \mu \mathrm{g} / \mathrm{g})$ & $29.2^{\mathrm{a}}$ & $17.8^{\mathrm{b}}$ \\
LPH $(150 \mu \mathrm{g} / \mathrm{g})$ & $26.9^{\mathrm{a}}$ & $17.8^{\mathrm{b}}$ \\
LPH $(200 \mu \mathrm{g} / \mathrm{g})$ & $27.4^{\mathrm{a}}$ & $15.5^{\mathrm{b}}$ \\
\hline
\end{tabular}

Organoleptic properties of burger were evaluated for appearance, color, juiciness, tenderness, flavor and overall acceptability. Table 3 illustrated sensory evaluation of beef burger containing different concentrate of LPH $(100,150$ and $200 \mu \mathrm{g} / \mathrm{g})$ compared to nisin $(200 \mu \mathrm{g} / \mathrm{g})$ as a positive control. The obtained results proved the high acceptability of all samples and the acceptability score for burgers produced were not significantly different $(\mathrm{p}>0.05)$ from the control and the fortified samples [41].

Table 4: Sensory evaluation of beef burger (negative control; NC) as supplemented with LPH at different concentrations (100, 150 and $200 \mu \mathrm{g} / \mathrm{g}$ ) compared to nisin $(200 \mu \mathrm{g} / \mathrm{g})$ as a positive control (PC).

\begin{tabular}{|c|c|c|c|c|c|c|}
\hline Treatments & 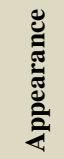 & $\frac{\grave{\sigma}}{2}$ & 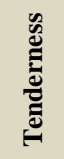 & 氖 & $\frac{\dot{\theta}}{\dot{\theta}}$ & 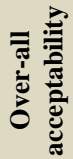 \\
\hline NC (without treatment) & $7.8^{\mathrm{a}}$ & $5.0^{\mathrm{c}}$ & $6.3^{\mathrm{b}}$ & $6.6^{\mathrm{ab}}$ & $7.0^{\mathrm{a}}$ & $90^{\mathrm{a}}$ \\
\hline PC (Nisin; $200 \mu \mathrm{g} / \mathrm{g}$ ) & $7.0^{\mathrm{bc}}$ & $6.0^{\mathrm{a}}$ & $7.0^{\mathrm{a}}$ & $6.2^{\mathrm{c}}$ & $7.0^{\mathrm{a}}$ & $90^{\mathrm{a}}$ \\
\hline LPH $(100 \mu \mathrm{g} / \mathrm{g})$ & $7.8^{\mathrm{a}}$ & $5.2^{\mathrm{c}}$ & $6.2^{\mathrm{b}}$ & $6.0^{\mathrm{bc}}$ & $6.8^{\mathrm{a}}$ & $89^{\mathrm{a}}$ \\
\hline LPH $(150 \mu \mathrm{g} / \mathrm{g})$ & $7.0^{\mathrm{bc}}$ & $5.8^{\mathrm{ab}}$ & $6.8^{\mathrm{a}}$ & $7.0^{\mathrm{a}}$ & $8.0^{\mathrm{a}}$ & $90^{\mathrm{a}}$ \\
\hline $\mathrm{LPH}(200 \mu \mathrm{g} / \mathrm{g})$ & $7.6^{\mathrm{ab}}$ & $5.4^{\mathrm{bc}}$ & $6.8^{\mathrm{a}}$ & $7.4^{\mathrm{a}}$ & $7.6^{\mathrm{a}}$ & $90^{\mathrm{a}}$ \\
\hline
\end{tabular}

\section{CONCLUSION}

The results of this study showed that enzymatic hydrolysis by alcalase at $\mathrm{pH} 7.8$ and $55^{\circ} \mathrm{C}$ for $240 \mathrm{~min}$ is an easy tool to increase the antibacterial activity of lupin protein against both gram negative and gram positive bacteria and can be used as a bio-preservative in food system. Extending the technological validity of minced beef will help avoid big losses of minced beef and enhance its chances to be incorporated into many meat products while avoiding hygienic, chemical and technological deterioration.

\section{REFERENCES}

1. Alzoreky N.S, Nakahara K. Antibacterial activity of extracts from some edible plants commonly consumed in Asia. International Journal of Food Microbiology. 2003; 80 (3): 223-230.

2. Shan B, Cai Y-Z, Brooks JD, Corke H. The in vitro antibacterial activity of dietary spice and medicinal herb extracts. International Journal of Food Microbiology. 2007; 117 (1): 112-119.

3. Viuda-Martos M, Mohamadyb MA, Fernández-Lópeza J et al. In vitro antioxidant and antibacterial activities of essentials oils obtained from Egyptian aromatic plants. Food Control. 2011; 22: 1715-1722.

4. Beuchat LR. In: Dillon VM, Board RG (eds.) Natural antimicrobial systems and food preservation. CAB, Wallingford, UK, 1994, p 167180.

5. Walker JRL. In: Dillon VM, Board RG (eds.) Natural antimicrobial systems and food preservation. CAB, Wallingford, UK, 1994, pp 181204.

6. Arora DS, Kaur J. Animicrobial activity of spices. International Journal of Antimicrobial Agents. 1999; 12: 257-262.

7. Marino M, Bersani C, Comi G. Antimicrobial activity of the essential oils of Thymus vulgaris L. measured using a bioimpedometric method. Journal of Food Protection. 1999; 62: 1017-1023.

8. Mahgoub S, Osman A, Sitohy M. Inhibition of Growth of Pathogenic Bacteria in Raw Milk by Legume Protein Esters. Journal of Food Protection. 2011; 74 (9): 1475-1481.

9. Mahgoub S, Sitohy M, Osman A. Counteracting Recontamination of Pasteurized Milk by Methylated Soybean Protein. Food and Bioprocess Technology. 2013; 6:101-109.

10. Sitohy M, Mahgoub S, Osman A. Controlling psychrotrophic bacteria in raw buffalo milk preserved at $4{ }^{\circ} \mathrm{C}$ with esterified legume proteins. LWT - Food Science and Technology. 2011; 44: 1697-1702.

11. Sitohy M, Mahgoub S, Osman A. In vitro and in situ antimicrobial action and mechanism of glycinin and itsbasic subunit. International Journal of Food Microbiology. 2012; 154: 19-29.

12. Sitohy M, Mahgoub S, Osman A, El-Masry R, Al-Gaby A. Extent and mode of action of cationic legume proteins against Listeria monocytogenes and Salmonella Enteritidis. Probiotics and Antimicrobial Proteins. 2013; 5:195-205.

13. Osman A, Mahgoub S, El-Massry R, El-Gaby A, Sitohy M. Extending the Technological Validity of Raw Buffalo Milk at Room Temperature by Esterified Legume Proteins. Journal of Food processing and preservation. 2014; 38, 223-231.

14. Osman A, Mahgoub S, Sitohy M. Preservative action of 11S (glycinin) and 7S ( $\beta$-conglycinin) soyglobulin on bovine raw milk stored either at 4 or $25^{\circ}$ C. Journal of Dairy Research. 2013; 80: 174-183.

15. Osman A, Mahgoub S, Sitohy M.Hindering milk quality storage deterioration by mild thermization combined with methylated chickpea protein. International Food Research Journal.2014; 21(2): 693-701.

16. Pereira P, Huerta B, Borge C, Astorga R, Romero R, Perea A. 2004. Antimicrobial activity of five essential oils against origin strains of the Enterobacteriaceae family. Acta Pathologica, Microbiologicaet Immunologica Scandinavica. 2004; 113(1): 1-6.

17. Joray ML, Rayas-Duarte P, Mohamed A, Van Santen E. Coated lupin beansnacks. Journal of Food Quality. 2007; 30(2): 267-279.

18. Yeheyis L, Kijora C, Wink M, Peters KJ. Effect of a Traditional processing method on the chemical composition of local white lupin (Lupinusalbus L.) seed in north-western Ethiopia. Zeitschrift Fur 
Naturforschung Section C-A Journal of Biosciences. 2011; 66(7-8): 403-408.

19. Torres A, Frias J, Vidal-Valverde C. Changes in chemical composition of lupin seeds (Lupinus angustifolius) after selective alpha-galactoside extraction. Journal of the Science of Food and Agriculture. 2005; 85(14): 2468-2474.

20. Sitohy M, Osman A. Antimicrobial activity of native and esterified legume proteins against Gram-negative and Gram-positive bacteria. Food Chemistry. 2010; 120:66-73.

21. Osman A, Goda HA, Abdel-Hamid M, Badran SM, Otte J. Antibacterial peptides generated by Alcalase hydrolysis of goat whey. LWT - Food Science and Technology.2016; 65: 480-486.

22. Théolier J, Hammami R, Labelle P, Fliss I, Jean J.Isolation and identification of antimicrobial peptides derived by peptic cleavage of whey protein isolate. Journal of Functional Foods. 2013; 5: 706 -714.

23. Sukan G, Andrews AT. Application of the plastein reaction to caseins and to skim milk powder. I. Protein hydrolysis and plastein formation. Journal of Dairy Research. 1982; 49:265-278.

24. Fox PF. The milk protein system. In Developments in Dairy Chemistry. Vol. 4. P. F. Fox, ed. Elsevier Applied Science, London, UK. 1989, P 1-53.

25. Rebeca BD, Pena-Vera MT, Díaz-Castañeda M. Production of fish protein hydrolysates with bacterial proteases; yield and nutritional value. Journal of Food Science. 1991; 56: 309-314.

26. Espejo-Carpio F, De Gobba C, Guadix A, Guadix E, Otte J.Angiotensin I-converting enzyme inhibitory activity of enzymatic hydrolysates of goat milk protein fractions. International Dairy Journal. 2013; 32: 175-183.

27. Sila A, Naima N, Karima H, Gabrielle C, Rafik B, Moncef, N, Pascal D, Ali B. Antibacterial peptides from barbel muscle protein hydrolysates: Activity against some pathogenic bacteria. LWT - Food Science and Technology. 2014; 55: 183-188.

28. Johnson EA, Brekke J. Functional properties of acylated pea protein isolates. Journal of Food Science. 1983; 48: 722-725.

29. Adler-Nissen J. Enzymic hydrolysis of food proteins. Barking. UK: Elsevier Applied Science Publishers; 1986.

30. Organisation of Economic Co-operation and Development (OECD). The OECD Guideline for Testing of Chemical: 420 Acute Oral Toxicity. OECD, Paris, France; 2001.

31. Nanda A, Saravanan M.Biosynthesis of silver nanoparticles from Staphylococcusaureus and its antimicrobial activity against MRSA and MRSE. Nanomedicine: Nanotechnology, Biology and Medicine. 2009; 5: $452-456$

32. Niehius WG, Samuelson B. Formation of malondialdehyde from phospholipid arachidonate during microsomal lipid peroxidation. European Journal of Biochemistry. 1968; 6: 126-130.
33. APHA Standard methods for the examination of water and waste water, $18^{\text {th }}$ edition. American public health association, Washington, D. C.; 1992.

34. Lee T. The liberal media myth revisited: An examination of factors influencing; 2005.

35. A.O.A.C. Official Methods of Analysis, 18th ed. A.O.A.C. International, MD, USA (1250 p.); . 2000.

36. Mansour EH, Khalil. Evaluation of antioxidant activity of some plant extracts and their application to ground beef patties. Food Chemistry. 2000; 69:135-141.

37. Yokota S, Fujii N. Contributions of the lipopolysaccharide outer core oligosaccharide region on the cell surface properties of Pseudomonas aeruginosa. Comparative Immunology, Microbiology \& Infectious Diseases.2007; 30:97-109.

38. Modi VK, Mahendrakar NS, Narasimha D, Sachindra NM. Quality of buffalo meat burger containing legume flours as binders J. Food Engineering. 2003; 66: 143-149.

39. Fernandez-Gines JM, Fernandez-Lopez J, Sayas- Barbera E, PerezAlvarez JA. Meat products as functional foods. Food Science.2005; 70: 37-43.

40. Mahmoud AH, Yehia G, Moharram MB, Magdi OE. Frozen storage stability of beef burger containing plat meat substitutes. Food Chemistry. 1987; 26(4): 261-269.

41. Akesowan A. Quality characteristics of light pork burgers fortified with soy protein isolate. Food science and biotechnology. 2010; 19:1143-1149.

\section{How to cite this article:}

Ali Osman, GhadaM. El-Araby, Hefnawy Taha., Potential use as a bio-preservative from lupin protein hydrolysate generated by alcalase in food system. J App Biol Biotech. 2016; 4 (02): 076081. DOI: $10.7324 / J A B B .2016 .40212$ 